\title{
Creative Education for Gifted Children
}

\author{
Fernanda Hellen Ribeiro Piske, Tania Stoltz, Jarci Machado \\ Federal University of Parana, Curitiba, Brazil \\ Email: nandahellen@hotmail.com, tania.stoltz795@googlemail.com, jarcimachado.0202@gmail.com
}

Received 17 March 2014; revised 17 April 2014; accepted 24 April 2014

Copyright (C) 2014 by authors and Scientific Research Publishing Inc.

This work is licensed under the Creative Commons Attribution International License (CC BY).

http://creativecommons.org/licenses/by/4.0/

c) (i) Open Access

\begin{abstract}
Creativity is an essential attribute for the development of creative potential. However, it is not always developed properly in the school context, especially when it is about gifted students education. Because these children need a specialized service to attend their special needs. In this sense, this study aims to contribute in order that education professionals reflect and become aware of the importance of creativity in education. The method of this research was based on national and international studies which focused on the area of High Abilities/Giftedness and creativity in the school context. The conclusion is that the development of creativity depends on a good teacher education in preparing activities that arouse curiosity and interest of each gifted, enabling the student creative and independent, investigative and critical thinking. Furthermore, teachers should provide new opportunities of reflection on the process of teaching and learning.
\end{abstract}

\section{Keywords}

Education; Creativity; Gifted

\section{Introduction}

The creative act arouses the emotions and feelings of each individual. Creativity has been discussed as an important aspect in the process of teaching and learning, however, many schools still adopt educational measures to repress this attribute. Considering someone creative in a particular area through partial psychometric or experimental studies is not appropriate, because these studies are limited to reveal the essence of creativity, therefore, it is important to consider the specificity of each individual.

According to Martínez (1997: p. 125), the complexity of the psychological determination of creativity cannot be understood by partial psychometric or experimental studies, due to the fact that its quantitative or relatively artificial nature is too limited to reveal its essence.

Our conception of personological character of creativity implies intensive study of the individual case, with the goal of trying to approach the individual configuration of personological elements (structural and functional), 
which are regulating creative behavior and, on that basis, to explore possible regularities in psychological determination (Martínez, 1997: p. 125). This author is right to consider every human being as an integral and different individual because each person has his/her unique characteristics of personality.

In the school context, in general, creativity is not being developed as it should be. Most students often feel unmotivated because of a monotonous and repetitive teaching. This lack of motivation happens primarily with gifted children who "make their discoveries by themselves and invent new ways of understanding. And because they have such fury to dominate, they are different from other children that work very hard to do their activities" (Winner, 1998: p. 247). Winner explains clearly that gifted students have different characteristics from other students in the regular room and need special services.

Several studies and surveys indicate that students with giftedness are extremely creative and require a compatible attendance for their special educational needs (de Alencar, 2001, 2007; Peterson, 2003; Renzulli, 2004; Pérez, 2004; Piske, 2011, 2013; Piske \& Stoltz, 2013; Prieto, Soto, \& Fernandez, 2013, among others).

However, the creative potential of gifted students has not received adequate attendance in the school context, most times teachers are not prepared to attend them. Teachers need to understand the differences and needs of their gifted students. The interaction among students is essential for the procedures adopted during classes because education involves its practitioners in a constant learning process. It is important to learn about the differences of each individual, education focuses on participation of individuals and how to deal with different situations in participatory proposal of negotiation and agreement (Werle, 2003: p. 29).

\section{Development of Creativity at School}

Educational practices are important to develop the creative potential. Bahia \& Trindade (2013: pp. 23-25) point out some important topics for the development of creativity at school, among them, we can list: implementation of a global climate that incite the construction of ideas, autonomy and openness to difference rather than conformity and uniformity that so often invades the school; use of different media to express and evaluate ideas, production ideas that reveal variety of possibilities or ways of thinking involves the ability to perspective under multiple possibilities; originality and innovation, because creativity is original and originator of alternative and unique possibilities, such as the infrequency of proposals and non-use of stereotyped images should be considered in school, this dimension involves the production of unique or unusual ideas, relevant ideas but not obvious, from the collection and synthesis of information in innovative ways; elaboration and expressiveness, therefore the elaboration refers to details that clarify an idea, concept, theme, or solution, enhancing its understanding and impact, the richness of communication of ideas and the presence of emotional dimension are essential strategies for a creative school (Bahia \& Trindade, 2013: pp. 23-25).

\section{Characteristics of Gifted}

In the school context, it is perceived that gifted children have different characteristics from the others in their group who have the same of them. These children engage in activities of their interest. Regarding the dedication of gifted children in their activities, Gama (2006: p. 83) says that gifted children have an excessive devotion to do things of their interest, which is not seen in children that have the same age. It is a high ability of concentration for periods of time, this ability is superior if we compare to abilities of other students in the same conditions and the same age. It is the ability to focus a lot on some activity, is a task, a lesson, the development of a project or any other work. (Gama, 2006: p. 83).

\section{Full Inclusion of Gifted}

Creative individuals as gifted students need specialized attendance for each area of development. Piske (2011, 2013) explains that to have a full inclusion of students with high abilities in schools, it is necessary not just attend their cognitive needs, education professionals need to be well prepared to attend also their emotional and social needs. For this, it is essential that schools provide measures of broader inclusion, such as the hiring of good teachers, pedagogues and psychologists prepared to attend this demand.

According to the proposal of school inclusion, it is important to prepare teachers to attend the special needs of gifted, involving the teaching method, teaching resources, interesting forms of learning for students with special needs, their school progress, evaluation issues among other aspects. Beyer (2006: p. 57) expresses that for 
teachers work, for whom the proposed school inclusion emerges as an additional "complicating” should try to provide an ongoing education with basic tools, with training to have good teachers. Evidently this training should have the essential requirements for a reasonable direction for the teaching-learning process, from conceptual foundations of integrative/inclusive education by implicit pedagogical aspects in this process, such as teaching method, teaching resources, forms of learning of students with special needs, their school progress, evaluation issues and other important aspects of school to promote the full inclusion (Beyer, 2006: p. 57).

Learning characteristics of students with special needs are important for their proper performance. The curricular organization presents controversies that should be discussed by the teachers and the whole school, because it not always come inclusive measures. According Beyer (2006: p. 69) the curriculum does not change. With the exception of the most severe cases of disability, the student attends a regular school. Then we can think of the training curriculum for students with special educational needs on a common basis to other students, since the principle of inclusive education is not to get rid of anybody of the general conditions of school progression. The curriculum does not have fundamental changes, however, the learning characteristics of students with special needs are undoubtedly taken into account (Beyer, 2006: p. 69).

Although many teachers think it is not difficult to find gifted students during classes, there are a lot of these students who have high abilities and high creative potential that need a proper attendance to develop their potentials and talents. Guenther (2006: p. 36) points out that it can be expected that 3\% to 5\% of the school population present abilities significantly above average compared to other children of their group, in various areas of human characteristics, including those valued by society, principles based on the concept of giftedness and talent. In most cases, these students should not create problems for teachers and their fellows in the school situation, which it does not mean they are not going to face difficulties and problems caused mainly by inadequate performance, expectations and inclinations ignored by the school and the inevitable boredom left by the low level of mental stimulation (Guenther, 2006: p. 36).

\section{Definition of the Area High Abilities/Giftedness}

It is essential to understand the characteristics of gifted and also know how to define the area high abilities/giftedness to have an appropriate specialized service for these children.

Taucei, Stoltz, Gabardo, (2013: p. 268) explain that the area of high ability/giftedness can be defined as a multidimensional phenomenon involving academic, intellectual, motor, social and artistic skills, while also including various features of human development.

The concept of high ability/gifted is in the documents about Special Education of Brazil. The National Policy on Special Education in the Perspective of Inclusive Education of the Brazilian Ministry of Education provides the following definition: Students with high ability/gifted demonstrate high potential in any of the following areas, singly or in combination: intellectual, academic, leadership, psychomotor and arts. They have also high creativity, high involvement in learning and performing activities in areas of their interest (Política Nacional, 2008: p. 15).

According to Renzulli (2004) there are two types of giftedness. A school or academic giftedness identified through standardized or informal identification techniques. Renzulli (2004: p. 82) explains:

It is the kind most easily measured by standardized tests of ability, it exists in varying degrees, it can be easily identified through standardized and informal techniques of identification and thus we should do everything within our possibilities to make appropriate modifications for students who are capable of winning the material of regular curriculum with pace and higher levels of understanding than their peers (Renzulli, 2004: p. 82).

Renzulli (2004: p. 83) also points out that there is a creative-productive giftedness that is based on the use and application of knowledge and thought processes, as the following definition: this kind of giftedness describes those aspects of human activity and which encourages the development of ideas, products, unique artistic expressions and knowledge areas that are purposely designed to have an impact on one or more target audiences. The situations of learning designed to promote creative-productive giftedness emphasize the use and application of knowledge and thought processes and an integrated inductive and oriented way to a real problem (Renzulli, 2004: p. 83).

In the school context, there are still many myths related to gifted education that influence the conceptions of many teachers generating misconceptions about these children (Piske, 2011, 2013).

It is possible to highlight some myths, such as gifted individuals are considered self-sufficient and because of this, they do not need specialized attendance, at other times they are considered as individuals that bother in 
class because of their frequent curiosities. Sometimes they are perceived as subjects who criticize other colleagues; other times they are perceived as individuals who only like reading or studying or individuals who always know everything (Mettrau, 1997: p. 13).

\section{Identification of Gifted Students}

To prevent myths that confuse education professionals during the process of identification of gifted individuals, Virgolim (2007: p. 17) points out some important tips to identify these children properly. Among them we can mention:

1) Nomination made by teachers: teachers are in a more favorable position to indicate students who have other characteristics than those not traditionally indicated by intelligence tests.

2) Indicators of creativity: indicators of creative thinking of students as well as formal tests of creativity can be useful to help the teacher to identify both those students whose creativity is apparent, as those whose unique and original talents may not be visible in the classroom.

3) Nomination made by parents: no one knows the children better than their parents. These individuals are in an advantageous position to offer a broad view of the peculiar development of the children, including interests and skills developed early.

4) Nomination by colleagues: colleagues know well each other and they are especially useful in indicating talents among different students culturally who have disabilities or from minority groups.

5) Self-nomination: a self-nomination can be a useful tool to favour this indication. A simple way is to ask students to "to indicate (s) area (s) in which he/she has skills or special talents, and he/she should say why he/she thinks he/she has special skills or talents in these areas." The areas to be indicated can be specific school subjects (Portuguese, mathematics, science, history, geography, arts, theater, music, languages, etc.). Besides, creativity, leadership, sports and general intellectual ability.

6) Special nomination: this form of naming is interesting because sometimes the teacher manages to get in some time of school student life, high performance in specific school subjects, however, if such opportunities did not recur in later years, the student cannot come to have another chance to demonstrate their skills or interests, losing a valuable opportunity to work in more depth their areas of interest. Thus, it is recommended that the staff responsible for selecting students seek information about the student with their teachers from previous years, whenever this is possible.

7) Evaluation of products: an excellent way to evaluate talents in artistic, creative and scientific areas is simply observing the production quality of the students in these specific areas.

8) Scales of features and lists of observations: scales and lists of characteristics are widely used in conjunction with indications of teachers, peers, fathers, and mothers of the students and evaluation of the product.

9) Nomination by student motivation: the nomination of students may occur at any time of the school year. Thus, the teacher can also designate for the attendance any student who has demonstrated an unusual interest in any subject, subject or topic that is being studied at that time (Virgolim, 2007: p. 17).

\section{Educational Practices for Gifted Inclusion}

In the educational context, it is necessary to have the support of a teaching staff that has access to specialized training to attend gifted students, teachers must have access to additional materials to attend the needs of these children, the curriculum must be appropriate for inclusive educational practices, there should be curriculum enrichment programs that include all levels of teaching, it is also necessary to have efficient techniques to identify gifted students.

There are many challenges to overcome in the area of High Abilities/Giftedness. There is an urgent need for inclusive measures for gifted students. Virgolim (2007: p. 18), indicates some of these measures, such as:

- Specialized training of teachers;

- Appropriate material to the needs of groups;

- Apropriate curriculum and programs for different levels in public and private schools;

- Graduation and postgraduation at Brazilian universities and specific area;

- Modern techniques of identification;

- Increased researches related to this population for the Brazilian reality;

- More specialized literature in our language. 


\section{Characteristics of Creative Thinking}

It is important to instigate curiosity and desire of learning of gifted students. For this, it is essential to understand their creative potential and their specificities. The way of thinking of students with high potential, often differs from the way that other students think, because generally gifted present in their thinking many details that are present in a single idea, their answers are uncommon and they present different forms of answers when they are questioned. Alencar (2009: p. 31) expresses some characteristics of creative thinking, listed below:

- Quantity of details contained in an idea;

- Decision process, judgment and selection of one or more ideas presented previously;

- Infrequent or unusual answers;

- Abundance or amount of different ideas on the same subject;

- Ability to change the thought or design different categories of responses (Alencar, 2009: p. 31).

The learning process of gifted children becomes effective when teachers begin to understand the needs of their students who have a high potential and require activities that represent challenges.

It is concluded that the development of creativity depends on a good teacher training in preparing activities that instigate the curiosity and interest of each gifted, allowing the student a creative, independent, investigative and critical thinking (Burg, 1992; Robinson, 1992; Renzulli, 1997; Wu, 2000; Landau, 2002; Alencar, 2009; Piske, 2013) furthermore, teachers should provide new opportunities in order to exist more reflection on the process of teaching and learning.

\section{References}

Alencar, E. M. L. S. (2001). Criatividade e educação de superdotados. Petrópolis, RJ: Vozes.

Alencar, E. M. L. S. (2007). Características sócio-emocionais do superdotado: questões atuais. Psicologia em estudo (Online), 12, 371-378. http://www.scielo.br/pdf/pe/v12n2/v12n2a18.pdf

Alencar, E. M. L. S. (2009). Como desenvolver o potencial criador: um guia para a liberação da criatividade em sala de aula. Petrópolis, RJ: Vozes.

Bahia, S., \& Trindade, J. P. (2013). Transformar o velho em novo: a integração da criatividade na educação. Em: Piske, F. H. R. e Bahia, S. (Coords.). Criatividade na escola: o desenvolvimento de potencialidades, altas habilidades/superdotação $(A H / S D)$ e talentos. Curitiba: Juruá.

Beyer, H. O. (2006). Inclusão e avaliação na escola de alunos com necessidades educacionais especiais. Porto Alegre: Mediação.

Burg, B. (1992). Gifted Education in Israel. Roeper Review, 14, 217-220. http://dx.doi.org/10.1080/02783199209553434

Gama, M. C. S. S. (2006). Educação de superdotados: teoria e prática. São Paulo: EPU.

Guenther, Z. C. (2006). Capacidade e Talento: Um programa para a escola. São Paulo: EPU.

Landau, E. (2002). A coragem de ser superdotado. São Paulo: A \& C.

Martínez, A. M. (1997). Criatividade, Personalidade e Educação. Campinas, SP: Papirus.

Mettrau, M. B. (1997). Representação Social da Inteligência e as Altas Habilidades. In: Seminário Nacional da ABSDInteligência: Patrimônio Social, XI, Anais (pp. 9-20). Rio de Janeiro: UERJ.

Peterson, J. S. (2003). Underachievers: Students Who Don’t Perform. In J. F. Smutny (Ed.), Underserved Gifted Populations (pp. 307-332). Creskill: Hampton.

Piske, F. H. R. (2011). Diversidade e inclusão: o direito à educação de alunos superdotados. Em: X Congresso Nacional de Educação-Educere-I Seminário Internacional de Representações Sociais, Subjetividade de Educação—SIRSSE, 2011, Curitiba. X Congresso Nacional de Educação-Educere-I Seminário Internacional de Representações Sociais, Subjetividade de Educação-SIRSSE (pp. 151-161). Curitiba: Champagnat. http://educere.bruc.com.br/CD2011/pdf/4341 2306.pdf

Piske, F. H. R. (2013). O desenvolvimento socioemocional de alunos com altas habilidades/superdotação (AH/SD) no contexto escolar: contribuições a partir de Vygotsky. Dissertação (Mestrado em Educação), Curitiba: Universidade Federal do Paraná.

Piske, F. H. R., \& Stoltz, T. (2013). Criatividade na escola: a necessidade de reavaliar as práticas educacionais aos alunos superdotados. Em: Piske, F. H. R. e Bahia, S. (Coords.). Criatividade na escola: o desenvolvimento de potencialidades, altas habilidades/superdotação (AH/SD) e talentos. Curitiba: Juruá.

Política Nacional (2008). Política nacional de educação especial na perspectiva da educação inclusiva do ministério da educação. Brasília, DF: MEC/SEESP. 
Prieto, M. D., Soto, G., \& Fernández, M. C. (2013). El aula como espacio creativo. Em: Piske, F. H. R. e Bahia, S. (orgs.). Criatividade na escola: o desenvolvimento de potencialidades, altas habilidades/superdotação (AH/SD) e talentos. Curitiba: Juruá.

Renzulli, J. S. (2004). O que é esta Coisa Chamada Superdotação, e Como a Desenvolvemos? Uma retrospectiva de vinte e cinco anos. Educação, Porto Alegre, ano XXVII, 75-131.

Renzulli, J. S., \& Reis, S. M. (1997). The Schoolwide Enrichment Model: A How-To Guide for Educational Excellence (2 ${ }^{\text {nd }}$ ed.). Mansfield Center, CT: Creative Learning Press.

Robinson, M. A. (1992). Vision Splendid: Gifted Education in Australia. Roeper Review, 14, 206-208. http://dx.doi.org/10.1080/02783199209553431

Taucei, J. R., Stoltz, T., \& Gabardo, C. V. (2013). Caminhos e descaminhos: a trajetória complexa do aluno com AH/SD e Dislexia na escola. Cadernos de Educação-UFPel (Online), 265-292.

Virgolim, A. M. R. (2007). Altas Habilidades/Superdotação: encorajando potenciais. Brasília: Ministério de EducaçãoMEC, Secretária de Educação Especial-SEESP.

Werle, F. O. C. (2003). Conselhos Escolares: Implicações na Gestão da Escola Básica. Rio de Janeiro: DP \& A.

Winner, E. (1998). Crianças superdotadas: mitos e realidades. Porto Alegre: Artmed.

Wu, W. T. (2000). Gifted polices in Taiwan. Gifted Education Internacional, 14, 56-65. http://dx.doi.org/10.1177/026142949901400107 